\title{
sciendo
}

\section{INFLUENCE OF RAW PEA (PISUM SATIVUM) OR BLUE LUPIN SEEDS (LUPINUS ANGUSTIFOLIUS) ON THE LEVEL OF SELECTED BIOACTIVE SUBSTANCES IN PORK MEAT*}

\author{
Marcin Sońta, Monika Łukasiewicz-Mierzejewska`, Kamila Puppel, Anna Rekiel, Justyna Więcek, Martyna Batorska \\ Institute of Animal Science, Warsaw University of Life Sciences, Ciszewskiego 8, \\ 02-786 Warszawa, Poland \\ •Corresponding author: monika_lukasiewicz@sggw.edu.pl
}

\begin{abstract}
The study objective was to evaluate the impact of different contributions of pea (Pisum sativum) cultivar Hubal and blue lupin (Lupinus angustifolius) cultivar Regent on the level of selected bioactive substances in pork meat. One hundred three cross-breed piglets: $q$ (Landrace $\times$ Yorkshire) $\times \curvearrowright$ Duroc were used. Two experiments were performed, in which pea seeds (experiment I: E1 - 5.0\% pea seeds; E2 - $\mathbf{1 0 . 0} \%$ pea seeds; E3 - $\mathbf{1 5 . 0 \%}$ pea seeds; E4 - $\mathbf{1 7 . 5 \%}$ pea seeds) and blue lupin seeds (experiment II; D1 - $\mathbf{5 . 0} \%$ blue lupin seeds; D2 $-\mathbf{1 0 . 0} \%$ blue lupin seeds; D3 - $\mathbf{1 5 . 0} \%$ blue lupin seeds D4 - $\mathbf{1 7 . 5 \%}$ blue lupin seeds) were used instead of genetically modified soybean meal (SBM-GM). In each of the experiments 50 animals were divided into 5 groups (control - C, and four experimentals), placed in group pens, each for 10 individuals (sex ratio barrows : gilts - 1:1). The animals were weighed and tagged before the experiments. The initial body weight of the pigs at experiment I and II commencement was: 26.7 and $33.5 \mathrm{~kg}$, and at the end of the experiments: 122.0 and 124.0 , respectively. In the first experiment (progressive pea "seeds" contribution) the concentration of carnosine was shown to be higher in E4 than $\mathrm{E} 3$ and $\mathrm{C}$ by $\mathbf{4 7 . 3 \%}$ and $\mathbf{9 4 . 2 \%}$, respectively. In comparison with group $\mathrm{C}$, the Q10 coenzyme content in groups E1, E2, E3 and E4 was lower by $\mathbf{4 0 . 9} \%, \mathbf{5 6 . 8} \%, \mathbf{4 0 . 9} \%$ and $\mathbf{6 5 . 9} \%$ respectively. In the experiment II (progressive lupin "seeds" contribution) increased content of all of the investigated bioactive substances was recorded in groups D1-D3 vs C. Significant differences between groups C, D2, D4 for taurine $(\mathrm{P} \leq \mathbf{0 . 0 5} ; \mathrm{P} \leq \mathbf{0 . 0 1})$ and creatine $(\mathrm{P} \leq \mathbf{0 . 0 5})$ have been recorded. The content of bioactive substances in the longissimus lumborum muscle was significantly influenced by legumes, which increased the level of bioactive components of protein fraction. Therefore, it can be concluded that pea (Pisum sativum) cultivar Hubal and blue lupin (Lupinus angustifolius) cultivar Regent are an alternative to SBM-GM, increasing the nutritional value of pork meat.
\end{abstract}

Key words: fattening pigs, nutrition, pea seeds, lupin seeds, meat, peptides

Pork meat is the second most-consumed meat type in the world. Predictions of global pigmeat consumption for 2025 indicate that consumption will be $12,5 \mathrm{~kg} /$ citizen/year (Szücs and Vida, 2017). Despite the growing consumer interest in this type of meat, information on its nutritional value, and in particular the content of bioactive substances is scarce (Kołodziej-Skalska et al., 2016).

Bioactive peptides are fragments of amino acid sequences of proteins, remaining inactive in their precursors, yet when freed from their parent proteins by proteolytic enzymes, they may act as modulators for a series of processes occurring in the organism (Darewicz et al., 2008). A biopeptide should exhibit biological effect or effects, which can be confirmed in a specific manner, in addition they should be beneficial for the health (Möller et al., 2008). The level of bioactive substances in the meat is determined by a variety of factors, with the most important including: animal species and breed, husbandry system, nutrition, muscle and cutting type, as well as its processing technology (Arihara et al., 2001; Pravst et al., 2010; Cardenia et al., 2015; Łukasiewicz et al., 2018). Biologically active compounds found in foods influence human and animal organisms. They may have antioxidative and anticancer effects, they accelerate metabolism, improve digestion and reduce blood pressure and blood glucose levels (Lafarga and Hayes, 2014). Thus, modification of the content of these substances in meat should be of interest to consumers and producers.

Nowadays, post-extraction soybean meal is the main source of protein in feed mixes for pigs. According to FEFAC (2015), 90\% of the post-extraction soybean meal available on the market and genetically modified plant derivatives are used for feed and consumption purposes. Research shows that genetic modifications do not affect animal production results and the quality and nutritional value of the obtained meat (Padgette et al., 1996; Aurlich et al., 2003; Flachowsky et al., 2005). What is more, no transfer of transgenic DNA to animal tissues could 
be verified (Świątkiewicz et al., 2011). The research results have not convinced some social groups in numerous countries, however, who require the elimination of products created with GM organisms from animal and human nutrition. Thus, alternative sources of proteins for humans as well as livestock are looked for, providing consumption products (meat, milk, eggs) to reduce the use of GM products. Livestock feeding requirements are met by legumes (pea, faba bean, sweet lupins), which can be successfully used in feed mixes for pigs (Sońta and Rekiel, 2017). Leguminosae is a large family with over 18,000 species of climbers, herbs, shrubs and trees. However, the most popular are: peas, broad beans, lentils, soybeans, lupins, lotus, sprouts, mung beans, green beans, etc. (Yorgancilar and Bilgicli, 2014). Legumes are an excellent source of good-quality protein in the range of 20 to $45 \%$, including peas have $17-20 \%$ protein, and lupins have $38-45 \%$ protein (Kouris-Blazos and Belski, 2016). Protein from legumes is an excellent source of bioactive peptides. Bioactive peptides from enzymes of legume proteins exhibit a spectrum of biological activity, from nutraceuticals to therapeutic potential. Bioactive plant peptides (similar to those found in muscle tissue) fulfill a range of functions, including the protection against pathogens, infection, regulate growth and development. In order to increase the consumption of bioactive peptides, an important strategy is to increase its concentration in vegetable food via optimum yield management. It should be noted that studies concerning the correlations between the introduced agronomic practice and natural levels of peptides are scarce among the numerous scientific reports on the identification and characteristics of the available bioactive plant peptides (Farrokhi et al., 2008;
Belovic et al., 2011; Ortiz-Martinez et al., 2014). What is more, there are no data on the impact of available bioactive peptides from plant protein hydrolysis on human organism in the plant-animal-human chain.

The antioxidant capacity of legumes allows them to inhibit or slow down oxidative processes (Maphosa and Jideani, 2016). The exhaustion of antioxidant systems is one of the reasons for the occurrence of oxidative stress, which results in avalanche production of reactive oxygen species or free radicals. Puppel et al. (2015) point out the direct relationship between the excess of free radicals and the lowering of animal resistance and their susceptibility to diseases. Bearing in mind the above, increasing the level of antioxidants is beneficial from the point of view of animal welfare and meat antioxidant potential.

The study objective was to evaluate the impact of different contributions of the selected legumes: pea (Pisum sativum) cultivar Hubal and blue lupin (Lupinus angustifolius) cultivar Regent used in pig nutrition on the level of bioactive compounds such as: carnosine, anserine, Q10 coenzyme, taurine and creatine and creatinine in the longissimus lumborum muscle.

\section{Material and methods}

In line with Polish law and the EU Directive (no. 2010/63/EU) (2010), the experiment did not require approval of the local Ethics Committee, because it was performed at a private farm (in production conditions).

Two experiments on growing pigs were performed, in the nutrition of which pea and blue lupin seeds were used instead of SBM-GM.

Table 1. Contribution (\%) of raw materials in feed mixtures administered at stage I and II of fattening in experiment I

\begin{tabular}{|c|c|c|c|c|c|c|}
\hline \multirow{2}{*}{\multicolumn{2}{|c|}{ Raw feed materials }} & \multicolumn{5}{|c|}{ Groups } \\
\hline & & $\mathrm{C}$ & E1 & E2 & E3 & E4 \\
\hline & 1 & 2 & 3 & 4 & 5 & 6 \\
\hline \multicolumn{7}{|c|}{ Fattening stage I } \\
\hline Barley & & 35.0 & 30.0 & 25.0 & 15.0 & 5.0 \\
\hline Triticale & & 24.0 & 19.2 & 20.3 & 22.1 & 28.3 \\
\hline Wheat & & 20.0 & 25.0 & 25.0 & 30.0 & 30.0 \\
\hline Oats & & 5.0 & 5.0 & 5.0 & 5.0 & 5.0 \\
\hline Soybean meal GM & & 13.0 & 9.7 & 8.3 & 6.4 & 2.0 \\
\hline Rapeseed meal & & - & 2.5 & 2.5 & 2.5 & 7.8 \\
\hline Pea seeds & & - & 5.0 & 10.0 & 15.0 & 17.5 \\
\hline Soybean oil & & - & 0.6 & 0.9 & 1.0 & 1.4 \\
\hline Premix* & & 3.0 & 3.0 & 3.0 & 3.0 & 3.0 \\
\hline \multicolumn{7}{|c|}{ Analyzed nutritional value (\%) } \\
\hline Dry matter & & 87.6 & 87.4 & 86.9 & 87.3 & 87.5 \\
\hline Crude protein & & 16.4 & 16.5 & 16.3 & 16.5 & 16.3 \\
\hline Ether extract & & 2.6 & 2.7 & 2.7 & 2.7 & 2.8 \\
\hline Crude fiber & & 3.9 & 3.9 & 4.0 & 4.1 & 4.1 \\
\hline Crude ash & & 3.9 & 4.0 & 3.9 & 4.1 & 3.9 \\
\hline
\end{tabular}




\begin{tabular}{|c|c|c|c|c|c|}
\hline 1 & 2 & 3 & 4 & 5 & 6 \\
\hline \multicolumn{6}{|c|}{ Calculated nutritional value (\%) } \\
\hline Metabolizable energy (MJ/kg) & 13.22 & 13.21 & 13.21 & 13.21 & 13.21 \\
\hline Lysine & 1.05 & 1.06 & 1.09 & 1.10 & 1.10 \\
\hline Methionine + Cysteine & 0.64 & 0.64 & 0.64 & 0.63 & 0.67 \\
\hline Threonine & 0.70 & 0.71 & 0.71 & 0.71 & 0.72 \\
\hline Tryptophan & 0.20 & 0.19 & 0.19 & 0.19 & 0.19 \\
\hline Calcium & 0.81 & 0.82 & 0.82 & 0.82 & 0.86 \\
\hline Phosphorus & 0.54 & 0.55 & 0.55 & 0.54 & 0.58 \\
\hline Sodium & 0.17 & 0.19 & 0.21 & 0.23 & 0.24 \\
\hline \multicolumn{6}{|c|}{ Fattening stage II } \\
\hline Barley & 35.0 & 25.0 & 15.0 & 10.0 & 8.2 \\
\hline Triticale & 32.0 & 26.5 & 30.0 & 30.0 & 30.0 \\
\hline Wheat & 10.0 & 21.6 & 24.7 & 30.0 & 30.0 \\
\hline Oats & 10.0 & 10.0 & 10.0 & 6.9 & 5.0 \\
\hline Soybean meal GM & 10.5 & 6.6 & 4.8 & 3.0 & - \\
\hline Rapeseed meal & - & 2.5 & 2.5 & 2.2 & 6.0 \\
\hline Pea seeds & - & 5.0 & 10.0 & 15.0 & 17.5 \\
\hline Soybean oil & - & 0.3 & 0.5 & 0.4 & 0.8 \\
\hline Premix* & 2.5 & 2.5 & 2.5 & 2.5 & 2.5 \\
\hline \multicolumn{6}{|c|}{ Analyzed nutritional value (\%) } \\
\hline Dry matter & 86.8 & 86.4 & 87.0 & 86.7 & 86.1 \\
\hline Crude protein & 15.3 & 15.4 & 15.5 & 15.2 & 15.1 \\
\hline Ether extract & 2.5 & 2.6 & 2.6 & 2.6 & 2.7 \\
\hline Crude fiber & 4.1 & 4.2 & 3.9 & 4.2 & 3.9 \\
\hline Crude ash & 4.5 & 4.7 & 4.5 & 4.7 & 4.6 \\
\hline \multicolumn{6}{|c|}{ Calculated nutritional value (\%) } \\
\hline Metabolizable energy (MJ/kg) & 13.17 & 13.16 & 13.17 & 13.17 & 13.16 \\
\hline Lysine & 0.94 & 0.94 & 0.95 & 0.96 & 0.97 \\
\hline Methionine + Cysteine & 0.60 & 0.61 & 0.61 & 0.60 & 0.61 \\
\hline Threonine & 0.64 & 0.64 & 0.64 & 0.64 & 0.65 \\
\hline Tryptophan & 0.18 & 0.18 & 0.18 & 0.17 & 0.17 \\
\hline Calcium & 0.68 & 0.70 & 0.69 & 0.69 & 0.71 \\
\hline Phosphorus & 0.51 & 0.51 & 0.51 & 0.50 & 0.52 \\
\hline Sodium & 0.15 & 0.17 & 0.19 & 0.21 & 0.21 \\
\hline
\end{tabular}

*Premix composition: lysine $-12.10 \%$; methionine $-2.65 \%$; threonine $-5.05 \%$; tryptophan $-0.25 \%$; calcium $-20.50 \%$; phosphorus $-1.80 \%$; sodium - 5.00\%; iron - 4,000 mg; manganese - $2400 \mathrm{mg}$; zinc - $2600 \mathrm{mg}$; copper - $800 \mathrm{mg}$; iodine - 55.0 mg; selenium - $13.50 \mathrm{mg}$; vitamin A - 260,000 IU; vitamin $\mathrm{D}_{3}-69,000 \mathrm{IU}$; vitamin $\mathrm{E}-4700 \mathrm{mg}$; vitamin $\mathrm{K}_{3}-68 \mathrm{mg}$; vitamin $\mathrm{B}_{1}-68 \mathrm{mg}$; vitamin $\mathrm{B}_{2}-170 \mathrm{mg} ;$ vitamin $\mathrm{B}_{6}-105 \mathrm{mg}$; vitamin $\mathrm{B}_{12}-830 \mathrm{mcg}$; vitamin C-1,000 mg; folic acid - $27.00 \mathrm{mg}$; pantothenic acid - $410 \mathrm{mg}$; niacinamide $\mathrm{B}_{3}-690 \mathrm{mcg}$; biotin - 3,450 mg; choline chloride - $10,000 \mathrm{mg}$; Aroma, antioxidant: 1b (E320-BHA, E321-BHT, E324 - Ethoxyquin) 550 mg/kg; Enzymes: 4a E-1 6406 - phytase (EC 3.1.3.2.6 n-5000 FTU/g) 17 500 FTU/kg, (E1600 endo 1,4-beta-xylanase, EC 3.2.1.8 - 22,000 VU/g; 425,000 VU/kg, endo 1.3 beta-glucanase EC 3.2.1.6 - 30,000 VU/g, 57 000 VU/kg); raw material composition: calcium carbonate, monocalcium phosphate, (monophosphate) sodium chloride 1.8 .1 .9 , herbal mix $10 \mathrm{~g} / \mathrm{kg}$.

\section{Animals and housing}

For two experiments, one hundred three cross-breed piglets: $q$ (Landrace $\times$ Yorkshire $) \times \hat{~} \curvearrowright$ Duroc were used. The animals were weighed and tagged prior to the experiments. The initial body weight of the pigs at experiment I and II commencement was: 26.7 and $33.5 \mathrm{~kg}$, and at the end of the experiments: 122.0 and 124.0, respectively. Fifty animals were divided into 5 groups for each experi- ment (control - C, and experimental - E1, E2, E3, E4), and were placed in group pens, each for 10 individuals (sex ratio: barrow : gilts $-1: 1$ ). The husbandry conditions complied with the Regulation of the Ministry of Agriculture and Rural Development of 15 February (2010). Experiment I was conducted between 23 December 2016 and 22 March 2017 and experiment II from 10 November 2017 to 23 January 2018. 
Table 2. Contribution (\%) of raw materials in feed mixtures administered at stage I and II of fattening in experiment II

\begin{tabular}{|c|c|c|c|c|c|}
\hline \multirow{2}{*}{ Raw feed materials } & \multicolumn{5}{|c|}{ Groups } \\
\hline & $\mathrm{C}$ & D1 & D2 & D3 & D4 \\
\hline \multicolumn{6}{|c|}{ Fattening stage I } \\
\hline Barley & 36.6 & 12.0 & 11.0 & 5.4 & 2.3 \\
\hline Triticale & 15.0 & 30.0 & 30.0 & 33.0 & 35.0 \\
\hline Wheat & 25.0 & 33.7 & 35.0 & 35.0 & 33.0 \\
\hline Oats & 5.0 & 3.0 & - & - & - \\
\hline Soybean meal GM & 15.0 & 10.5 & 8.0 & 5.5 & 2.0 \\
\hline Rapeseed meal & - & 2.5 & 2.5 & 2.5 & 6.0 \\
\hline Blue lupin seeds & - & 5.0 & 10.0 & 15.0 & 17.5 \\
\hline Soybean oil & 0.4 & 0.3 & 0.5 & 0.6 & 1.2 \\
\hline Premix* & 3.0 & 3.0 & 3.0 & 3.0 & 3.0 \\
\hline \multicolumn{6}{|c|}{ Analyzed nutritional value (\%) } \\
\hline Dry matter & 87.7 & 87.4 & 87.3 & 87.1 & 87.4 \\
\hline Crude protein & 16.3 & 16.4 & 16.3 & 16.2 & 16.4 \\
\hline Ether extract & 2.6 & 2.6 & 2.7 & 2.7 & 2.8 \\
\hline Crude fiber & 3.9 & 3.9 & 4.2 & 4.2 & 4.1 \\
\hline Crude ash & 3.9 & 4.1 & 4.1 & 4.1 & 3.9 \\
\hline \multicolumn{6}{|c|}{ Calculated nutritional value (\%) } \\
\hline Metabolizable energy (MJ/kg) & 13.23 & 13.19 & 13.20 & 13.21 & 13.20 \\
\hline Lysine & 1.09 & 1.06 & 1.04 & 1.03 & 1.05 \\
\hline Methionine + Cysteine & 0.66 & 0.65 & 0.64 & 0.63 & 0.64 \\
\hline Threonine & 0.72 & 0.71 & 0.70 & 0.70 & 0.71 \\
\hline Tryptophan & 0.21 & 0.20 & 0.19 & 0.19 & 0.18 \\
\hline Calcium & 0.87 & 0.89 & 0.89 & 0.89 & 0.91 \\
\hline Phosphorus & 0.53 & 0.52 & 0.51 & 0.50 & 0.51 \\
\hline Sodium & 0.17 & 0.18 & 0.18 & 0.18 & 0.18 \\
\hline \multicolumn{6}{|c|}{ Fattening stage II } \\
\hline Barley & 36.7 & 12.0 & 11.4 & 8.8 & 5.8 \\
\hline Triticale & 20.0 & 30.0 & 30.0 & 33.0 & 35.0 \\
\hline Wheat & 20.0 & 32.3 & 35.0 & 35.0 & 33.0 \\
\hline Oats & 8.0 & 7.5 & 3.0 & - & - \\
\hline Soybean meal GM & 12.8 & 8.2 & 5.6 & 3.1 & - \\
\hline Rapeseed meal & - & 2.5 & 2.5 & 2.5 & 5.6 \\
\hline Blue lupin seeds & - & 5.0 & 10.0 & 15.0 & 17.5 \\
\hline Soybean oil & - & - & - & 0.1 & 0.6 \\
\hline Premix* & 2.5 & 2.5 & 2.5 & 2.5 & 2.5 \\
\hline \multicolumn{6}{|c|}{ Analyzed nutritional value (\%) } \\
\hline Dry matter & 87.6 & 87.9 & 87.4 & 87.5 & 88.0 \\
\hline Crude protein & 15.4 & 15.6 & 15.3 & 15.2 & 15.3 \\
\hline Ether extract & 2.2 & 2.1 & 2.3 & 2.2 & 2.3 \\
\hline Crude fiber & 3.9 & 3.8 & 4.2 & 4.0 & 4.1 \\
\hline Crude ash & 4.0 & 3.9 & 4.0 & 4.1 & 4.3 \\
\hline \multicolumn{6}{|c|}{ Calculated nutritional value (\%) } \\
\hline Metabolizable energy (MJ/kg) & 13.20 & 13.19 & 13.19 & 13.19 & 13.20 \\
\hline Lysine & 0.98 & 0.95 & 0.96 & 0.96 & 0.96 \\
\hline Methionine + Cysteine & 0.63 & 0.63 & 0.61 & 0.60 & 0.60 \\
\hline Threonine & 0.66 & 0.65 & 0.65 & 0.64 & 0.65 \\
\hline Tryptophan & 0.19 & 0.19 & 0.18 & 0.17 & 0.17 \\
\hline Calcium & 0.74 & 0.75 & 0.76 & 0.76 & 0.78 \\
\hline Phosphorus & 0.50 & 0.49 & 0.48 & 0.47 & 0.48 \\
\hline Sodium & 0.14 & 0.15 & 0.15 & 0.15 & 0.16 \\
\hline
\end{tabular}

*Premix composition - see: Table 1. 


\section{Nutrition}

Complete mixes in bulk, administered ad libitum, with constant access to water were used in the 2-stage fattening (experiment I: 88 days; experiment II: 73 days) (Table 1 and 2). The pigs were fed with balanced feed, as per the recommendations (Grela and Skomiał, 2015).

Amino acid content determinations were performed with the gas chromatography method at the Central Agro-ecological Laboratory of the Lublin University of Life Sciences, according to the internal procedures of the laboratory (CLA/PLC/20, CLA/PLC/34) (Table 3).

Table 3. Amino acid content in pea and blue lupin seeds (mg/g d.w.)

\begin{tabular}{l|c|c}
\hline \multicolumn{1}{c|}{ Amino acids } & $\begin{array}{c}\text { Pea seeds } \\
\text { cv. Hubal }\end{array}$ & $\begin{array}{c}\text { Blue lupin seeds } \\
\text { cv. Regent }\end{array}$ \\
\hline Lysine & 15.30 & 12.30 \\
Methionine & 1.83 & 1.66 \\
Leucine & 15.20 & 16.70 \\
Isoleucine & 8.50 & 9.38 \\
Histidine & 5.34 & 6.69 \\
Phenylalanine & 10.20 & 9.38 \\
Threonine & 8.30 & 8.79 \\
Tryptophan & 1.62 & 7.56 \\
Valine & 9.57 & 9.24 \\
Arginine & 18.70 & 29.00 \\
Tyrosine & 6.05 & 8.07 \\
Cysteine & 3.66 & 4.40 \\
Alanine & 9.23 & 8.86 \\
Glycine & 9.01 & 10.20 \\
Aspartic acid & 25.10 & 24.80 \\
Glutamine & 41.10 & 59.90 \\
Serine & 10.80 & 12.10 \\
Proline & 9.74 & 10.90 \\
\hline & & \\
\hline & & \\
\hline
\end{tabular}

\section{Analysis of bioactive substances}

After the completion of the fattening, all animals were subject to slaughtering according to the procedures of the plant. After 24-hour cooling at the temperature of $+4^{\circ} \mathrm{C}$, samples of the longissimus lumborum muscle (MLL) (approx. $0.5 \mathrm{~kg}$ ) were collected for the study from the right half carcasses. Approximately $200 \mathrm{~g}$ of muscle sample was ground in a machine with revolving blades and mixed. The material was secured and frozen.

The levels of bioactive peptides - carnosine, anserine (Lukasiewicz et al., 2015), Q10, creatine, creatinine, taurine (Purchas et al., 2004) in the muscles were determined using the reverse-phase high-performance liquid chromatography RP-HPLC Agilent 1100 (Agilent Technologies, Waldbronn, Germany) and a Jupiter C18 300A column (Phenomenex, Torrance, CA, USA). The mobile phase A comprised of acetonitrile mixture with water (30:70) and 0.1\% TFA acid (both reagents by Merck), phase $\mathrm{B}-$ acetonitrile mixture with water (70:30) and
$0.1 \%$ TFA. The flow through-column was $1.4 \mathrm{ml} / \mathrm{min}$, at UV detection of $214 \mathrm{~nm}$. The qualitative analysis was performed using the calibration against the models: carnosine Lot \# CBB7948; anserine Lot \# BCBF45160, Q10 Lot \# SLBT6669, taurine Lot \# BCBJ5953V, creatine Lot \# CBAD0780, creatinine Lot \# CBBG4255 (Sigma-Aldrich, St Louis, MO, USA).

\section{Statistical analysis of results}

The results were statistically elaborated using the IBM SPSS Statistics 21 package, independently for the experiment I and II. The Shapiro-Wilk test was used to check the normal distribution. Differences between the groups were tested with the Kruskal-Wallis test. The tables present mean result and standard deviation. The differences were determined statistically significant at $\mathrm{P} \leq 0.05$ or $\mathrm{P} \leq 0.01$.

\section{Results}

Production results of this experiment already published in the journal Animals (Table 4) indicate that there is no contraindication to the use of pea and blue lupin seeds at $5.0 \%$ to $17.5 \%$ as alternative feed materials to SBM-GM in fattening pigs (Sońta et al., 2020). These results are beneficial from both environmental and consumer perspectives, hence the continued research towards bioactive peptides.

\section{Experiment I}

The lowest carnosine content was determined in group E2, and the highest in group E4 (Table 5). Highly statistically significant differences were confirmed between groups E3 vs C, E1 and E2, and E4 vs C, E1 and E2. Carnosine content in the meat of the experimental fattening pigs E3 and E4 in comparison with control C was higher by $47.3 \%$ and $94.2 \%$. The content of anserine was lowest in group E2, and in groups E3 and E4 approximately 2-fold higher vs. E2 $(\mathrm{P} \leq 0.01)$. The differences between E2 vs E3 and E4 were 100\% and 88\%, respectively.

The Q10 coenzyme content in all experimental groups was significantly lower than in control $(\mathrm{P} \leq 0.01)$, approx. 2-fold, and up to 3-fold (group E4 vs C). In comparison with group $\mathrm{C}$, the Q10 coenzyme content in groups E1, E2, E3 and E4 was lower by $40.9 \%, 56.8 \%, 40.9 \%$ and $65.9 \%$ respectively and it was not a directional correlation. The lowest taurine content in the tested longissimus lumborum muscle samples was recorded in the control group and in the experimental E2 group. The highest level of taurine was determined in the meat of pigs from group E3. Highly statistically significant differences (at $\mathrm{P} \leq 0.01$ ) were determined between groups $\mathrm{E} 3$ vs $\mathrm{C}, \mathrm{E} 1$ and $\mathrm{E} 2$, as well as $\mathrm{E} 4$ vs $\mathrm{C}$ and $\mathrm{E} 2$, and at $\mathrm{P} \leq 0.05$ between $\mathrm{E} 1$ and E4. Creatine level was at its highest in group E2, and lowest in group E3. Differences at $\mathrm{P} \leq 0.01$ were demonstrated between groups $\mathrm{C}$ vs E3 and E4; E1 vs E3; E2 
vs E3 and E4. The highest creatinine content was recorded for the longissimus lumborum muscle samples of the pigs from group $\mathrm{C}$, and the lowest from $\mathrm{E} 4(\mathrm{P} \leq 0.01)$.

\section{Experiment II}

Table 6 presents the results of the mean content of the tested bioactive substances in the longissimus lumborum muscle. The highest values for all of the studied bioac- tive substances were determined in group D2, fed with $10 \%$ addition of blue lupin. The lowest carnosine content was determined for group C. The content of anserine, Q10 coenzyme, taurine, creatine and creatinine was lowest in the longissimus lumborum muscles obtained from E4 pigs. Significant differences were recorded between groups $\mathrm{C}, \mathrm{D} 2$, D4 for taurine $(\mathrm{P} \leq 0.05 ; \mathrm{P} \leq 0.01)$ and creatine $(\mathrm{P} \leq 0.05)$.

Table 4. Daily body weight gains and meatiness of fatteners (Experiment I and II) ( $\bar{x}$, SD) Sońta et al. (2020)

\begin{tabular}{|c|c|c|c|c|c|c|}
\hline \multirow{2}{*}{ Item } & \multicolumn{5}{|c|}{ Groups $^{1}$} & \multirow{2}{*}{ P-value } \\
\hline & $\mathrm{C}$ & E1/D1 & E2/D2 & E3/D3 & E4/D4 & \\
\hline & \multicolumn{6}{|c|}{ Experiment I } \\
\hline Initial body weight (kg) & $26.4 \pm 1.1$ & $27.1 \pm 0.8$ & $26.9 \pm 0.9$ & $26.5 \pm 0.8$ & $26.5 \pm 1.0$ & 0.336 \\
\hline Final body weight (kg) & $123.4 \pm 9.6$ & $123.0 \pm 8.7$ & $124.8 \pm 7.5$ & $122.1 \pm 7.3$ & $116.5 \pm 9.7$ & 0.255 \\
\hline Average daily body weight gain (g) & $1104 \pm 119$ & $1090 \pm 97$ & $1113 \pm 87$ & $1086 \pm 80$ & $1022 \pm 108$ & 0.294 \\
\hline \multirow[t]{2}{*}{ Meatiness (\%) } & $60.0 \pm 0.8$ & $60.6 \pm 1.9$ & $60.1 \pm 2.3$ & $60.4 \pm 2.0$ & $59.7 \pm 2.4$ & 0.854 \\
\hline & \multicolumn{6}{|c|}{ Experiment II } \\
\hline Initial body weight (kg) & $33.5 \pm 1.4$ & $33.1 \pm 1.5$ & $33.9 \pm 1.5$ & $33.7 \pm 1.8$ & $33.4 \pm 1.5$ & 0.810 \\
\hline Final body weight (kg) & $125.5 \pm 8.7$ & $123.5 \pm 5.8$ & $125.1 \pm 4.9$ & $126.6 \pm 7.7$ & $121.1 \pm 7.4$ & 0.452 \\
\hline Average daily body weight gain (g) & $1260 \pm 118$ & $1238 \pm 82$ & $1249 \pm 70$ & $1272 \pm 107$ & $1201 \pm 92$ & 0.529 \\
\hline Meatiness (\%) & $58.9 \pm 1.9$ & $58.9 \pm 2.9$ & $58.9 \pm 2.0$ & $59.2 \pm 2.5$ & $58.1 \pm 2.5$ & 0.878 \\
\hline
\end{tabular}

${ }^{1} \mathrm{C}$ - soybean meal; E1 - 5.0\% pea seeds; E2 - 10.0\% pea seeds; E3 - 15.0\% pea seeds; E4 - 17.5\% pea seeds; D1 - 5.0\% blue lupin seeds; D2 - $10.0 \%$ blue lupin seeds; D $-15.0 \%$ blue lupin seeds; D $-17.5 \%$ blue lupin seeds.

Table 5. Content of bioactive substances in the longissimus lumborum muscle (mg/g) ( $\overline{\mathrm{x}}, \mathrm{SD})$

\begin{tabular}{|c|c|c|c|c|c|c|}
\hline \multirow{2}{*}{ Item } & \multicolumn{5}{|c|}{ Groups $^{1}$} & \multirow{2}{*}{ P-value } \\
\hline & $\mathrm{C}$ & E1 & E2 & E3 & E4 & \\
\hline Carnosine & $2.43 \mathrm{Aa} \pm 0.93$ & $2.44 \pm 1.09$ & $2.12 \mathrm{EF} \pm 0.49$ & $3.58 \mathrm{ACE} \pm 1.41$ & $4.72 \mathrm{BDF} \pm 1.65$ & 0.005 \\
\hline Anserine & $0.23 \pm 0.09$ & $0.22 \pm 0.14$ & $0.17 \mathrm{AB} \pm 0.06$ & $0.34 \mathrm{~A} \pm 0.29$ & $0.32 \mathrm{~B} \pm 0.11$ & 0.035 \\
\hline Q10 coenzyme & $0.044 \mathrm{ABCD} \pm 0.011$ & $0.026 \mathrm{~A} \pm 0.005$ & $0.019 \mathrm{~B} \pm 0.001$ & $0.026 \mathrm{C} \pm 0.007$ & $0.015 \mathrm{D} \pm 0.001$ & 0.001 \\
\hline Taurine & $0.17 \mathrm{Aa} \pm 0.02$ & $0.22 \pm 0.15$ & $0.17 \mathrm{DE} \pm 0.02$ & $0.37 \mathrm{ACD} \pm 0.17$ & $0.30 \mathrm{Bea} \pm 0.12$ & 0.002 \\
\hline Creatine & $2.46 \mathrm{AB} \pm 0.97$ & $2.05 \pm 1.12$ & $2.49 \mathrm{DE} \pm 0.93$ & $1.13 \mathrm{ACD} \pm 0.44$ & $1.78 \mathrm{BE} \pm 0.37$ & 0.005 \\
\hline Creatinine & $1.48 \mathrm{ABCD} \pm 0.38$ & $0.74 \mathrm{~A} \pm 0.51$ & $0.57 \mathrm{~B} \pm 0.32$ & $0.68 \mathrm{C} \pm 0.31$ & $0.47 \mathrm{D} \pm 0.14$ & 0.002 \\
\hline
\end{tabular}

${ }^{1} \mathrm{C}$ - soybean meal; E1 - 5.0\% pea seeds; E2 - 10.0\% pea seeds; E3 - 15.0\% pea seeds; E4 - $17.5 \%$ pea seeds.

$\mathrm{A}, \mathrm{A}$ - means in the lines marked with the same upper case letters differ significantly at $\mathrm{P} \leq 0.01$.

a, a- means in the lines marked with the same lower case letters differ significantly at $\mathrm{P} \leq 0.05$.

Table 6. Content of bioactive substances in the longissimus lumborum muscle (mg/g) $\overline{\mathrm{x}}, \mathrm{SD})$

\begin{tabular}{l|c|c|c|c|c|c|}
\hline \multirow{2}{*}{ Item } & \multicolumn{5}{c}{ Groups $^{1}$} & \multicolumn{2}{c}{ P-value } \\
\cline { 2 - 7 } & $\mathrm{C}$ & $\mathrm{D} 1$ & $\mathrm{D} 2$ & $\mathrm{D} 3$ & $2.50 \pm 0.76$ \\
Carnosine & $2.47 \mathrm{~A} \pm 0.46$ & $3.23 \pm 0.86$ & $3.60 \mathrm{a} \pm 0.98$ & $2.90 \pm 0.79$ & 0.048 \\
Anserine & $0.33 \pm 0.09$ & $0.39 \pm 0.07$ & $0.41 \pm 0.11$ & $0.34 \pm 0.09$ & $0.31 \pm 0.08$ & $0.059 \pm 0.013$ \\
Q10 coenzyme & $0.064 \pm 0.014$ & $0.071 \pm 0.016$ & $0.080 \pm 0.018$ & $0.066 \pm 0.015$ & 0.087 \\
Taurine & $0.20 \mathrm{~A} \pm 0.03$ & $0.23 \pm 0.03$ & $0.26 \mathrm{Aab} \pm 0.03$ & $0.21 \mathrm{~b} \pm 0.03$ & $0.19 \mathrm{~A} \pm 0.03$ \\
Creatine & $2.03 \pm 0.24$ & $2.25 \pm 0.26$ & $2.47 \mathrm{ab} \pm 0.31$ & $2.40 \pm 0.96$ & $1.93 \mathrm{~b} \pm 0.29$ \\
Creatinine & $1.06 \pm 0.22$ & $1.18 \pm 0.25$ & $1.33 \pm 0.28$ & $1.09 \pm 0.23$ & $0.98 \pm 0.21$ \\
\hline
\end{tabular}

${ }^{1} \mathrm{C}$ - soybean meal; D1 - 5.0\% blue lupin seeds; D2 - 10.0\% blue lupin seeds; D3 - 15.0\% blue lupin seeds; D4 - $17.5 \%$ blue lupin seeds.

$\mathrm{A}, \mathrm{A}-$ means in the lines marked with the same upper case letters differ significantly at $\mathrm{P} \leq 0.01$.

$\mathrm{a}, \mathrm{a}-$ means in the lines marked with the same lower case letters differ significantly at $\mathrm{P} \leq 0.05$. 


\section{Discussion}

Legumes are considered the second most important food source after cereals. Legumes are tasty, easily absorbable and nutritionally valuable (Petterson et al., 1997; Messina, 1999). providing bioactive compounds, such as protein, nutritional fiber, phenolic compounds, flavonoids, antioxidants, tocopherols, carotenoids, minerals and vitamins, which are responsible for preventing numerous diseases of civilization, including diabetes, cancers, cardiovascular diseases and other chronic disorders (Barbana and Boye, 2010; Amarowicz and Pegg, 2008; Frias et al., 2005). Tables 5 and 6 show changes in the concentration of carnosine for progressive pee and lupin contributions. The lowest content of carnosine was reported as $2.43 \mathrm{mg} / \mathrm{g}$ (Table 5, C group), while the highest was $4.72 \mathrm{mg} / \mathrm{g}$ (Table 5; E4 group). Carnosine was significantly $(\mathrm{P} \leq 0.01)$ influenced by legumes. Easter and Baker (1977) reported that carnosine content in pork meat ranges between 2.40 and $4.66 \mathrm{mg} / \mathrm{g}$, which is confirmed by the obtained results. Considering that the carnosine homeostasis regulation has been poorly studied, it proves difficult to explain unambiguously its progressive increase in the meat in experiment I. Our results are consistent with the earlier research (Cornet and Bousset, 1999), showing that the white muscle had higher carnosine content than the dark muscle. According to the model of homology by Vistoli et al. (2006), the carnosinase activity in the serum is stimulated by citrate. Schulz et al. (1989) observed that cAMP inhibits carnosine synthase activity. This study suggests that carnosine concentration is metabolically regulated.

Oxidative intermediate and oxidative slow twitch muscle fibers have been found in the longissimus dorsi muscle of wild pigs compared to domesticated pig breeds (Essén-Gustavsson and Lindholm, 1984). Therefore, the lower anserine content in pigs is likely correlated with the more pronounced oxidative metabolism, both in terms of the performed kinetic activity as well as the used hybrid. The lowest content of anserine was reported as $0.17 \mathrm{mg} / \mathrm{g}$ (Table 5, E2 group), while the highest was $0.41 \mathrm{mg} / \mathrm{g}$ (Table 6; D2 group). Anserine was significantly $(\mathrm{P} \leq 0.05)$ influenced by legumes. A reverse trend was observed for anserine - meat with the highest carnosine content was characterized by the lowest anserine content. In a summary, in reality the content of the mentioned peptides is not only influenced by the kinetic activity and the fiber type, but also the breed, sex, age or husbandry system (Abe and Okuma, 1995), as well as nutrition.

Taurine shows numerous physiological functions (osmotic pressure regulation, protection of cells against free radicals, influence on the development of the brain and the retina), it is also beneficial for cardiac muscle operation (Pasantes-Morales et al., 1990). Meat is a rich source of this compound, however its concentration depends on the meat and muscle type. Franco et al. (2010) reported that that the masseter muscle, followed by semimembranosus, and biceps femoris, had the highest concentration of taurine, where taurine accounted for 40,35 and $31 \%$ of the total free fraction, respectively. Taurine content in pork meat depends on the muscle type, and it is highly variable $(22.5-162.5 \mathrm{mg} / 100 \mathrm{~g})$. The lowest content of taurine was reported as $0.17 \mathrm{mg} / \mathrm{g}$ (Table 5 , C group), while the highest was $0.37 \mathrm{mg} / \mathrm{g}$ (Table 6; E3 group). Taurine was significantly $(\mathrm{P} \leq 0.01)$ influenced by legumes. Taurine is synthesized in mammalian organisms from sulfur amino acids, methionine and cysteine (Pasantes-Morales et al., 1990; Kulasek et al., 2004; Marušić et al., 2013). In the present experiment, the higher taurine content was perhaps influenced by the elevated supply of these amino acids in the mixes, through the increasing contribution of (pea) seeds in the nutrition in experiment I, groups E1-E4 vs C. Post-extraction soybean meal was the sole protein source in the control mix (present study). As stated by Biel (2011), the content of methionine and cysteine in genetically modified post-extraction soybean meal is lower than in legume seeds, which may result in reduced taurine synthesis.

The remaining bioactive substances determined in the present study also exhibit health-promoting properties. The Q10 coenzyme content in pork meat ranges between 13 and $45 \mathrm{mg} / 100 \mathrm{~g}$ (Pravst et al., 2010), which is not confirmed by the obtained results, because the lowered level has been reported. The lowest content of Q10 was reported as $0.015 \mathrm{mg} / \mathrm{g}$ (Table 5, E4 group), while the highest was $0.080 \mathrm{mg} / \mathrm{g}$ (Table 6; D2 group). Q10 coenzyme was significantly $(\mathrm{P} \leq 0.01)$ influenced by legumes. Tyrosine takes part in its synthesis, which has been confirmed in the present study (higher contribution of tyrosine in lupin seeds vs pea seeds likely determined the obtained result), as well as numerous vitamins (Folkers, 1996). However, variations in the coenzyme content have been observed for various species. The highest concentration of this coenzyme is found in the meat of ruminants (cattle and sheep), between 1.1 and $3.1 \mathrm{mg} / 100 \mathrm{~g}$, with the level of $3.92 \mathrm{mg} / 100 \mathrm{~g}$ in cattle liver. The presence of Q10 coenzyme in the organism is necessary for the normal course of numerous biochemical transformations. It is responsible for the production of high-energy compounds, used by the organism to supply the energy necessary for vital processes. This substance enhances the immune system, exhibits antioxidative action and prevents coronary heart disease; therefore, the increase in coenzyme Q10 obtained in the present experiments is beneficial to consumers.

The action of creatine and creatinine consists of a rapid supply of energy to muscles for their operation, which occurs through ADP to ATP conversion. Creatine synthesis occurs within the liver, kidneys and pancreas, and the organism utilizes arginine, methionine and glycine for this purpose (Mora et al., 2010). Creatine is dissolved to creatinine in the presence of water, low $\mathrm{pH}$ and elevated temperature (Pischel and Gastner, 2007), which may have practical significance for thermal processing of meat and production of processed products. The cited authors determined creatine and creatinine level in pork 
meat at 414 and $8.21 \mathrm{mg} / 100 \mathrm{~g}$, respectively, which is not confirmed by the obtained results, because the lowered level of creatine has been reported. The lowest content of creatine was reported as $1.13 \mathrm{mg} / \mathrm{g}$ (Table 5, E3 group), while the highest was $2.49 \mathrm{mg} / \mathrm{g}$ (Table 5; E2 group). Creatine was significantly $(\mathrm{P} \leq 0.01)$ influenced by legumes. Having analyzed the results of the present study as well as the selected, available literature devoted to the topic (Pravst et al., 2010), we could agree with the claim of Arihara et al. (2001), who believe that pork meat is a good source of bioactive substances. The cited authors provide the content of certain bioactive substances in pork meat: creatine $(247-347 \mathrm{mg} / 100 \mathrm{~g})$, carnosine (211-419 mg/100 g), taurine (50-72 mg/100 g), Q10 coenzyme (approx. $2 \mathrm{mg} / 100 \mathrm{~g}$ ).

\section{Conclusions}

The impact of feed minerals used in the nutrition of animals for slaughter on the quality of raw meat is an interesting issue. For this reason, the present study analyzed the content of several bioactive compounds in the pork meat obtained from the studied fattening pigs. An increase in the level of bioactive substances is highly beneficial from the health standpoint. The content of bioactive substances in the longissimus lumborum muscle was significantly influenced by legumes. Studies have shown that $10.0 \%$ blue lupin seeds had the most beneficial effect. Therefore, it can be concluded that pea (Pisum sativum) cultivar Hubal and blue lupin (Lupinus angustifolius) cultivar Regent is an alternative to SBM-GM, increasing the nutritional value of pork meat.

\section{Author contributions}

Conceptualization, M.S. and A.R.; methodology, M.S., M.Ł. and K.P.; software, M.B. and J.W.; validation, M.B. and J.W.; formal analysis, M.S., J.W. and M.B.; investigation, M.S., M.Ł. and A.R.; resources, M.Ł. AND K.P.; data curation, J.W. and M.B.; writing original draft preparation, M.S., M.Ł. AND A.R.; writing - review and editing, M.S., M.Ł. and A.R.; visualization, M.S.; supervision, A.R.; project administration, M.Ł.; funding acquisition, M.S. and A.R. All authors have read and agreed to the published version of the manuscript.

\section{Conflicts of interest}

The authors declare no conflict of interest.

\section{References}

Abe H., Okuma E. (1995). Discrimination of meat species in processed meat products based on the ratio of histidine dipeptides. Nippon Shokuhin Kagaku Kogaku Kaishi., 42: 827-834.

Amarowicz R., Pegg R.B. (2008). Legumes as a source of natural antioxidants. Eur. J. Lipid Sci. Technol., 110: 865-878.

Arihara K., Nakashima Y., Mukai T., Ishikawa S., Itoh M. (2001) Peptide inhibitors for angiotensin I-converting enzyme from enzymatic hydrolysates of porcine skeletal muscle proteins. Meat Sci., 57: 319-324.
Aurlich K., Bohme H., Daenicke R., Halle L.T., Flachovsky G. (2003). Genetically modified feeds in animal nutrition. Bacillus thuringiensis (Bt) corn in poultry, pig and ruminant nutrition. Arch. Anim. Nutr., 54: 183-195.

Barbana C., Boye J.I. (2010). Angiotensin I-converting enzyme inhibitory activity of chickpea and pea protein hydrolysates. Food Res. Int., 43: 1642-1649.

Belovic M.M., Mastilović J.S., Torbica A.L., Tomić J.M., Stanić D.R., Džinić N.R. (2011). Potential of bioactive proteins and peptides for prevention and treatment of mass non-communicable diseases. Food Feed Res., 38: 51-61.

Biel W. (2011). Composition and quality of protein of conventional and genetically-modified soybean meal. Folia Pomer (in Polish). Univ. Technol. Stetin. Agric. Aliment. Pisc. Zootech., 290: 17-24.

Cardenia V., Massimini M., Poerio A., Venturini M., Rodriguez-Estrada M., Vecchia P., Larcker G. (2015). Effect of dietary supplementation on lipid photooxidation in beef meat, during storage under commercial retail conditions. Meat Sci., 105: 126-135.

Cornet M., Bousset J. (1999). Free amino acids and dipeptides in porcine muscles: Differences between 'red' and 'white' muscles. Meat Sci., 51: 215-219.

Darewicz M., Dziuba J., Minkiewicz P. (2008). Celiac disease - background, molecular, bioinformatics and analytical aspects. Food Rev. Int., 24: 311-329.

Easter R.A., Baker D.H. (1977). Nitrogen metabolism, tissue carnosine concentration and blood chemistry of gravid swine fed graded levels of histidine. J. Nutr., 107: 120-125.

Essén-Gustavsson B., Lindholm A. (1984). Fiber types and metabolic characteristics in muscles of wild boars, normal and halothane sensitive Swedish Landrace pigs. Comp. Biochem. Physiol., 78: 67-71.

European Parliament and the Council of the European Union. Directive 2010/63/EU of the European Parliament and of the Council of 22 September 2010 on the protection of animals used for scientific purposes (2010). Official Journal of the European Union L., 276, 53: 33-79.

Farrokhi N., Whitelegge J.P., Brusslan J.A. (2008). Plant peptides and peptidomics. Plant Biotechnol., 6: 105-134.

FEFAC experts - private communication (2015).

Flachowsky G., Chesson A., Aurlich K. (2005). Animal nutrition with feeds from genetically modified plants. Arch. Anim. Nutr., 59: 1-40.

Folkers K. (1996). Relevance of the biosynthesis of coenzyme Q10 and of the four bases of DNA as a rationale for the molecular causes of cancer and a therapy. Biochem. Biophys. Res. Commun., 224: 358-361.

Franco D., Gonzáles L., Bispo E., Rodriquez P., Garabal J.I.I., Moreno T. (2010). Study of hydrolyzed protein composition, free amino acid, and taurine content in different muscles of Galician blonde beef. J. Muscle Foods, 21: 769-784.

Frias J., Miranda M.L., Doblado R., Vidal-Valverde C. (2005). Effect of germination and fermentation on the antioxidant vitamin content and antioxidant capacity of Lupinus albus L. var. Multolupa. Food Chem., 92: 211-220.

Grela E.R., Skomiał J. (2015). Zalecenia żywieniowe i wartość pokarmowa pasz dla świń. Normy żywienia świń (in Polish). IFiŻZ, Jabłonna.

Kołodziej-Skalska A., Matysiak B., Grudziński M. (2016). Pigmeat and the human health (in Polish). Kosmos, 65: 535-542.

Kouris-Blazos A., Belski R. (2016). Health benefits of legumes and pulses with a focus on Australian sweet lupins. Asian Pacific J. Clin. Nutr., 21: 1-17.

Kulasek G., Jank M., Sawosz E. (2004). Biological role of taurine in mammals (in Polish). Życie Wet., 79: 603-608.

Lafarga T., Hayes M. (2014). Bioactive peptides from meat muscle and by-products: generation, functionality and application as functional ingredients. Meat Sci., 98: 227-239.

Łukasiewicz M., Puppel K., Kuczyńska B., Kamaszewski M., Niemiec J. (2015). B-Alanine as a factor influencing the content of bioactive dipeptides in muscles of Hubbard Flex chickens. J. Sci. Food Agric., 95: 2562-2565. 
Łukasiewicz M., Puppel K., Balcerak M., Slósarz J., Gołębiewski M., Kuczyńska B., Batorska M., Więcek J., Kunowska-Slósarz M., Popczyk B. (2018). Variability of anserine and carnosine concentration in the wild boar (Sus scrofa scrofa) meat. Anim. Sci. Pap. Rep., 36: 185-192.

Maphosa Y., Jideani V.A. (2016). Physicochemical characteristics of Bambara groundnut dietary fibres extracted using wet milling. South Afr. J. Sci., 112: 1-8.

Marušić N., Aristoy M.C., Toldrá F. (2013). Nutritional pork meat compounds as affected by ham dry-curing. Meat Sci., 93: 53-60.

Messina M.J. (1999). Legumes and soybeans: overview of their nutritional profiles and health effects. Am. J. Clin. Nutr., 70: 439-450.

Möller N.P., Scholz-Ahrens K.E., Roos N., Schrezenmeir J. (2008) Bioactive peptides and proteins from foods: indications for health effects. Eur. J. Nutr., 47: 171-182.

Mora L., Hernández-Cázares A.S., Sentandreu M.A., Toldrá F. (2010). Creatine and creatinine evolution during the processing of drycured ham. Meat Sci., 84: 384-389.

Ortiz-Martinez M., Winkler R., Garcia-Lara S. (2014). Preventive and therapeutic potential of peptides from cereals against cancer. J. Proteomics, 111: 165-183.

Padgette S.R., Taylor N.B., Nida D.L., Bailey M.R., Mac Donald J., Holden L.R., Fusch R.L. (1996). The composition of glyphosatetolerant soybean seeds is equivalent to that of conventional soybeans. J. Nutr., 126: 702-716.

Pasantes-Morales H., Quesada O., Alcocer L., Olea R.S. (1990). Taurine content in foods. Nutr. Rep Int., 40: 793-801.

Petterson D.S., Sipsas S., Mackintosh J.B. (1997). The chemical composition and nutritive value of Australian pulses. 2nd ed. Canberra, Grains Research and Development Corporation.

Pischel I., Gastner T. (2007). Creatine - its chemical synthesis, chemistry, and legal status. Subcell Biochem., 46: 291-307.

Pravst I., Žmitek K., Žmitek J. (2010). Coenzyme Q10 contents in foods and fortification strategies. Crit. Rev. Food Sci., 50: 269280.

Puppel K., Kapusta A., Kuczyńska B. (2015). The etiology of oxidative stress in the various species of animals, a review. J. Sci. Food Agric., 95: 2179-2184.
Purchas R.W., Rutherfurd S.M., Pearce P.D., Vather R., Wilkinson B.H.P. (2004). Concentrations in beef and lamb of taurine, carnosine, coenzyme Q10 and creatine. Meat Sci., 66: 629-637.

Regulation of the Minister of Agriculture and Rural Development of 15 February 2010 on the requirements and handling procedures in production of livestock species for which the protection standards were stipulated in European Union Regulations (2010). Journal of Laws 2010; no. 56, item 344.

Schulz M., Hamprecht B., Kleinkauf H., Bauer K. (1989). Regulation by dibutyryl cyclic-AMP of carnosine synthesis in astroglia-rich primary cultures kept in serum-free medium. J. Neurochem., 52: 229-234.

Sońta M., Rekiel A. (2017). Production and use of legumes for fodder. Part II. The use of legumes in animal feeding (in Polish). Przegl. Hod., 1: 19-25.

Sońta M., Batorska M., Więcek J., Rekiel A. (2020). Performance results and concentrations of biochemical indices and mineral elements in blood serum of fatteners fed diets containing mixtures of raw seeds of pea (Pisum sativum L.) or blue lupin (Lupinus angustifolius $\mathrm{L}$.). Animals, 10: 1-12.

Świątkiewicz M., Hanczakowska E., Twardowska M., Mazur M., Kwiatek K., Kozaczyński W., Świątkiewicz S., Sieradzki Z. (2011). Effect of genetically modified feeds on fattening results and transfer of transgenic DNA to swine tissues. Bull. Vet. Inst. Pulawy, 55: 121-125.

Szücs I., Vida V. (2017). Global tendencies in pork meat - production, trade and consumption. Abstract. Appl. Stud. Agribus. Commerce, 11: 105-112.

Vistoli G., Pedretti A., Cattaneo M., Aldini G., Testa B. (2006). Homology modeling of human serum carnosinase, a potential medicinal target, and MD simulations of its allosteric activation by citrate. J. Med. Chem., 49: 3269-3277.

Yorgancilar M., Bilgicli N. (2014). Chemical and nutritional changes in bitter and sweet lupin seeds (Lupinus albus L.) during bulgur production. J. Food Sci. Technol., 51: 1384-1389.

Received: 9 II 2021

Accepted: 15 VI 2021 